\title{
Beck Depression Inventory (BDI-IA) adapted for HIV: Psychometric properties, sensitivity \& specificity in depressive episodes, adjustment disorder \& without symptomatology
}

\author{
Víctor Rodríguez-Pérez, ${ }^{1}$ Alicia Piñeirua Menéndez, ${ }^{2}$ Claudia Ramírez-Rentería, ${ }^{3}$ José Antonio Mata Marín ${ }^{4}$
}

Universidad Tecnológica de México - UNITEC MÉXICO Campus Ecatepec, Estado de México, México

2 Dirección de Atención Integral, Centro Nacional para la Prevención y Control del VIH y el sida, Ciudad de México, México.

3 UIM de Enfermedades Endócrinas, Hospital de Especialidades, Centro Médico Nacional Siglo XXI, Instituto Mexicano del Seguro Social, Ciudad de México, México.

4 Hospital de Infectología, CMN La Raza, Instituto Mexicano del Seguro Social, Ciudad de México, México.

\section{Correspondence:}

Víctor Rodríguez Pérez

Clínica de Adherencia a

Antirretrovirales y Polifarmacia de la

Clínica Especializada Condesa.

Gral. Benjamín Hill 24

Colonia Condesa,

06140 Cuauhtémoc

Ciudad de México, México.

Phone: +52 (55) 5515-8311

Email: victor.psicologoacademico@

gmail.com

Received: 11 May 2020

Accepted: 25 January 2021

Citation:

Rodríguez-Pérez, V., Piñeirua Menéndez, A., Ramírez-Rentería, C., \& Mata Marín. J. A. (2021). Beck Depression Inventory (BDI-IA) adapted for HIV: Psychometric properties, sensitivity \& specificity in depressive episodes, adjustment disorder \& without symptomatology. Salud Mental, 44(6), 287-294.

DOI: $10.17711 /$ SM.0185-3325.2021.037

\begin{abstract}
Introduction. The Beck Depression Inventory (BDI-IA) is the most widely used instrument for assessing depression symptoms. Although it has been validated in the Mexican population, it has not been tested in people living with HIV $(\mathrm{PLWH})$, who tend to have symptoms difficult to distinguish from those associated with viral infection. Objective. We obtained the psychometric properties, sensitivity, specificity, and cut-off points to distinguish between a depressive episode, adjustment disorder and no symptoms. Method. Prospective study with 2,022 PLWH ( $88 \%$ men), who completed the BDI-IA between 2016 and 2017 . Subjects had a mean age of $31.9 \pm 9.3$ years, with $12.0 \pm 5.6$ years of schooling, and $4.5 \pm 4.3$ years since diagnosis. The differentiation of items, internal consistency, factor analysis, and calculation of sensitivity and specificity were tested. Results. A Cronbach's alpha coefficient of .91 was obtained. Through factorial analysis with orthogonal rotation (average intercorrelations $r=.40$, KMO .929), we obtained three factors: general factor of depression, somatic, and cognition, which explained $39.7 \%, 6.01 \%$, and $5.49 \%$ of the variance, respectively. Only the items in the first factor (the short version with 12 items) were tested. With a cut-off point of 11 , it had $85.5 \%$ sensitivity and $76 \%$ specificity $[(A \cup C)=.865,95 \% \mathrm{Cl}[.83, .90], p \leq .001]$, and distinguished major depressive disorder from cases without mental symptoms. Discussion and conclusion. We show that the short version of the BDIIA is reliable, valid, sensitive, and specific for evaluating depression symptoms comorbid with HIV infection.
\end{abstract}

Keywords: Depression, HIV, reliability, validity.

\section{RESUMEN}

Introducción. El Inventario de Depresión de Beck (IDB-IA) es el instrumento más usado para evaluar síntomas depresivos, y aunque ha sido validado en población mexicana, no se ha probado en personas que viven con VIH (PVV), quienes suelen tener síntomas difíciles de distinguir de los asociados a infección viral. Objetivo. Obtuvimos las propiedades psicométricas, sensibilidad, especificidad y puntos de corte para distinguir entre episodio depresivo, trastorno adaptativo y sin síntomas. Método. Estudio prospectivo con 2,022 PVV (88\% hombres) quienes completaron el IDB-IA entre 2016 y 2017. La media de edad fue $31.9 \pm 9.3$ años, $12.0 \pm 5.6$ años de educación y $4.5 \pm 4.3$ años de diagnóstico. Se probó la diferenciación de reactivos, consistencia interna, análisis factorial y cálculo de la sensibilidad y especificidad. Resultados. Se obtuvo un coeficiente alfa de Cronbach de .91. Mediante el análisis factorial con rotación ortogonal (intercorrelaciones promedio $r=.40, \mathrm{KMO} .929$ ), obtuvimos tres factores: factor general de la depresión, somático y cognición; que explicaron el $39.7 \%, 6.01 \%, 5.49 \%$ de la varianza, respectivamente. Se probaron sólo los reactivos del primer factor (versión corta de 12 ítems) con un punto de corte de 11 , tuvo $85.5 \%$ de sensibilidad y $76 \%$ de especificidad $[(\mathrm{ABC})=.865, \mathrm{IC} 95 \%[.83, .90], p \leq .001]$ y diferenció el trastorno depresivo mayor de los casos sin sintomatología mental. Discusión y conclusión. Demostramos que la versión corta del IDB-IA es confiable, válida, sensible y específica para evaluar síntomas depresivos comórbidos a la infección por VIH.

Palabras clave: Depresión, VIH, confiabilidad, validez. 


\section{INTRODUCTION}

Since the emergence of antiretroviral treatment (ART) worldwide, infection by the human immunodeficiency virus (HIV) has no longer been regarded as fatal. Until 2018, a prevalence of $.18 \%$ to $.32 \%$ was estimated in the general population ages 15 to 49 , with new cases appearing every year. HIV causes immune dysfunction, which can become serious, progressive, and disabling when there are delays in case detection or in the absence of treatment (Censida, 2018a; Dávila, Castellanos, \& García, 2015).

In addition to immunosuppression and opportunistic diseases, infection-associated comorbidities have been described, including mental disorders (Censida, 2018b). Depression has been reported as one of the main mental health problems affecting people living with HIV (PLWH), as demonstrated by a reported prevalence between $12 \%$ and $40 \%$, obtained using various methodologies (Chichetto et al., 2020; Ciesla \& Roberts, 2001; Nanni, Caruso, Mitchell, Meggiolaro, \& Grassi, 2015; Vos et al., 2015; White et al., 2015; Wolff, Alvarado, \& Wolff, 2010).

Depression is defined as a mood disorder characterized by an individual's loss of the capacity to take an interest in and enjoy everyday things, expressed as sadness, loss of interest or pleasure, feelings of guilt or lack of self-esteem, sleep, or appetite disorders, feeling tired, and lack of concentration (American Psychiatric Association, 2015).

It has been reported that psychosocial factors such as stigma, social isolation, negative emotional burden, and self-stigma could be associated with certain mental health problems reported in PLWH. However, the tropism of the virus and the effects of antiretroviral treatment (ART) have also been found to be related to the presence of depression symptoms (Govender \& Schlebusch, 2012; Hudelson \& Cluver, 2015; Mendoza, Ramírez, \& Morales, 2013).

Screening and evaluating depression symptoms in this population is important because of the increase in these symptoms, which in turn are associated with the growth of physical health problems and a decrease in functionality related to the symptoms and chronicity of the infection itself (Berger-Greenstein et al., 2007; Gonzalez, Batchelder, Psaros, \& Safren, 2011; Hammond et al., 2016; Kalichman, Rompa, \& Cage, 2000). Depression symptoms are also linked to lower adherence to ART, reducing the subjective feeling of well-being and worsening the perception of overall health status. More objectively, failure to adhere to treatment can lead to resistance to ART drugs, the only treatment method currently available for HIV infection (Chichetto et al., 2020; Engler, Lènàrt, Lessard, Toupin, \& Lebouché, 2018; Nanni et al., 2015; Turan et al., 2019; Gebreyesus, Belay, Berhe, \& Haile, 2020; Uthman, Magidson, Safren, \& Nachega, 2014).

Depression symptoms and advanced stages of HIV infection (C3) may present similar symptoms: anergy, alter- ations in the sleep-wake cycle, appetite, psychomotor skills, libido, and cognitive function (Pala et al., 2016; Sowa, Bengtson, Gaynes, \& Pence, 2016).

Some researchers (Pala et al., 2016; Sowa et al., 2016; Tsai, 2014) have questioned the use of BDI-IA in PLWH because of the high correlations between the somatic component of depression and symptomatic variables of HIV infection, such as fatigue, wasting syndrome, the number of opportunistic diseases and the CD4 cell count. These findings indicate that symptomatic carriers should be evaluated with instruments that do not include questions on somatic factors, while depression scores require different interpretations from those for the general population.

Although there are currently several validated instruments for measuring depression in Mexico, none have demonstrated their psychometric properties and utility in PLWH. We therefore obtained the reliability, construct validity, sensitivity, and specificity of a short version of the BDI-IA for PLWH patients with depressive episode, adjustment disorder, and no depression symptoms.

We objective was obtain the internal consistency, factorial structure, sensitivity, and specificity of a short version of the BDI-IA in PLWH that enables one to evaluate and distinguish cases with a depressive episode, adjustment disorder, or no depression symptoms.

\section{METHOD}

\section{Study design}

This is a cross-sectional, prospective, correlational study conducted between January 2016 and December 2017.

\section{Place}

Leading public health institution in the diagnosis and treatment of HIV-infected patients living in Mexico City who do not receive care from any other health system.

\section{Measurements}

The Beck Depression Inventory (BDI-IA) is a self-administered questionnaire designed to measure depression symptoms during the past week (Valdés et al., 2017). The 21-item inventory has an answer scale with four points for each item, with total scores ranging from 0 to 63 points (Beck \& Steer, 1984; Beck, Steer, \& Carbin, 1988).

There are hundreds of published studies on the BDI-IA confirming its psychometric properties in different samples that support its cultural equivalence (Muhktar \& Oei, 2008; Steer, Clark, Beck, \& Ranieri, 1999). It has numerous advantages including the fact that since it is self-applicable, once it has been adapted and validated for a population, 
it can be used in everyday clinical practice (Torres-Castillo, Hernández-Malpica, \& Ortega-Soto, 1991). It can be administered by health personnel not involved in mental health, provided mechanisms are in place to refer patients in the event they test positive.

The BDI-IA groups these symptoms into various factors: cognitive-affective and somatic, which explain $37.41 \%$ and $6.28 \%$ of the variance respectively. Regarding reliability, internal consistency coefficients from .76 to .95 have been found, as well as (r) test-retest coefficients from .48 to .86 (Beltrán, Freyre, \& Hernández-Guzmán, 2012; González-Celis Rangel, 2009; Rodríguez et al., 2012; Tsai, 2014). The BDI-IA version, standardized by Jurado et al. (1998), is still widely used in Mexico. In the validation, they reported an internal consistency of .87 for the total inventory, mean correlations with the Zung Self-Rating Depression Scale of .65 , and in the factor analysis they reported three factors: negative attitudes towards oneself, performance deterioration, and somatic alteration.

We used the Mexican version of the BDI-IA (Jurado et al., 1998) and then we obtained a short version based on the results of the factor analysis using principal component analysis.

The mental health diagnosis made by the professional (a psychologist or a psychiatrist) was identified according to the criteria of the American Psychiatric Association (APA, 2015) and based on the codes in the International Classification of Diseases, Tenth Revision (ICD-10) (World Health Organization, 2000): no mental disorder symptoms, adjustment disorder symptoms, and major depressive disorder symptoms. In the case of adjustment disorder, the criteria included the emergence of emotional or behavioral symptoms in response to an identifiable stressor that occurs within three months of the presence of the stressor, clinically expressed as a) greater discomfort than expected in response to the stressor and b) significant impairment of social or work (or academic) activity. The criteria for major depressive disorder included five or more of the following symptoms for at least two weeks: low mood most of the time, anhedonia, hyporexia or hyperorexia, insomnia or hypersomnia, cognitive impairment, psychomotor impairment, anergy, ideas of disability or guilt, thoughts of death and suicidal ideation (APA, 2015).

\section{Inclusion criteria}

- Participants $>18$ years with a diagnosis of HIV infection.

- Having attended an evaluation session to start treatment, with an interconsultation with the internal medicine and/or infectious disease department.

- Having voluntarily participated in the study.

\section{Exclusion criteria}

- Having symptoms of advanced infection (stage C3).

- Having a diagnosis of a serious mental disorder: attempted suicide, difficult-to-treat major depressive disorder, bipolar disorder, schizophrenia, or any psychotic disorder.

\section{Procedure}

The study was conducted at a cutting-edge unit of the Mexico City Health Secretariat that provides outpatient care for PLWH over 18 years old. After the medical evaluation, all patients diagnosed with HIV were routinely assessed by the Mental Health service and the Antiretroviral Adherence Clinic of the unit. This assessment is randomly conducted by psychology personnel to detect any relevant psychopathology that could hamper or jeopardize the onset of antiretroviral therapy. If necessary, a psychiatric interconsultation and evaluation are undertaken. Subsequently, ART is begun by consensus in the Internal Medicine/Infectology department, based on the recommendations issued during this evaluation.

The study was conducted in two stages. The first, piloting the questionnaire, took place during the first two weeks. Patients who came to the clinic in those two weeks, from Monday to Thursday from 10 a.m. to 5 p.m., were invited to participate by filling out the questionnaire on their own. During this first phase, subjects were asked whether they understood the questions and the answer options to identify any misleading words in the application forms (Carretero-Dios \& Pérez, 2005; Guillemin, 1995).

During the second phase (application), all patients who attended from the third week of January 2016 to the third week of December 2017 were invited to participate at the same time from Monday to Thursday from 10 a.m. to 5 p.m. Those who agreed to participate filled out the informed consent form guaranteeing data confidentiality and the differential handling of the cases. They then proceeded to answer the cover sheet of the questionnaire that included variables such as age, gender, years of schooling, length of time since diagnosis, last value of viral load and CD4 cells, and the BDIIA version. Based on the calculation of the sample size of Mexican prevalence studies (Bautista-Arredondo, Colchero, Romero, Conde-Glez, \& Sosa-Rubí, 2013), and considering the estimated prevalence for CDMX and the probability that a man who has sex with men could be HIV positive, a minimum of 90 observations per month was considered. The study was conducted until the minimum sample was achieved.

\section{Statistical analysis}

SPSS Statistics 25 was used for the analysis. For the description of the sample, we used central tendency and variability measures for both the demographic variables and the viral 
load count and CD4 cells at the time of evaluation, as well as the Student's $t$ test to calculate the differences in sociodemographic variables $(p<.05)$. For the confirmatory factor analysis (CFA) with structural equations we used SPSS 22.

The data were analyzed according to the guidelines provided by Carretero-Dios and Pérez (2005), Nunnally and Bernstein, (1994) and Reyes-Lagunes and García y Barragán (2008) for psychometric assessment.

1. Item-by-item frequency analysis to determine whether all the answer options were attractive.

2. Discrimination analysis through Student's $t$ test with extreme quartiles. Items whose t was not significant $(p>.05)$ were eliminated.

3. Item-by-item cross tables to observe the direction.

4. Internal Consistency Analysis.

5. Items that passed the internal consistency criteria were used to make an intercorrelation to determine the type of rotation to be carried out in the factor analysis.

6. As moderate intercorrelations were obtained, an exploratory factor analysis with orthogonal rotation was conducted. The principal components were obtained, and the Cattell breaking point was revised to determine the number of real factors. To consider an item within a factor, we considered a factorial load of $\geq .40$.

7. Cronbach's alpha coefficient was obtained from the total number of questions that passed the factor analysis criteria, as well as for each of the factors.

8. A CFA was performed using the Maximum Likelihood method. The fit of the data to the model was evaluated based on current recommendations (Byrne, 2010), using the $\mathrm{X}^{2} / \mathrm{df}$ ratio, the mean square root of the approximation error (RMSEA), with its associated confidence interval of $90 \%$, the comparative fit index (CFI), and the Tucker-Lewis Index (TLI). Two unifactorial models and one with three factorial factors were evaluated to determine the degree of adjustment of each one to the structure of the questionnaire.

9. A short version of the IDB-IA was obtained with the 12 items that explained the highest percentage of the variance with the highest reliability coefficient and achieved acceptable parameters in the CFA.

10. The cut-off points were obtained from the distribution of the sample in the short, 12-question version (the factor with the highest percentage of explained variance). As for the mental health diagnosis, the sensitivity and specificity of those cut-off points were obtained, with the respective Receiver Operating Characteristic (ROC) curve.

\section{Ethical considerations}

Patients were invited to participate by researchers while they were waiting for this evaluation by the Mental Health Department, in keeping with the requirements of the Declaration of Helsinki 1975 for research in humans. The protocol was authorized by the Ethics Committe of the Condesa Specialized Clinic (Clínica Especializada Condesa).

Only subjects who agreed to participate answered the questionnaire, without receiving remuneration for their participation. When the questionnaires were collected, subjects were informed that, in addition to the fact that the confidentiality of their data would be guaranteed, if they needed to talk about any of the issues in the questionnaire or had any particular concern, they could make an appointment in the mental health area of the unit (World Medical Association, 2013).

\section{RESULTS}

Out of a total of 3,380 applicants who agreed to participate, 2,050 were diagnosed with adjustment disorder symptoms, major depressive disorder symptoms, or no symptoms of mental disorder. Twenty-eight applications (1\%) with more than three unanswered items were eliminated. This left 2,022 subjects ( $88 \%$ men) who had completed the questionnaire, with an average age of $31.9 \pm 9.3$ years, $12.0 \pm 5.6$ years of schooling and $4.5 \pm 4.3$ years since their confirmed diagnosis. Table 1 shows the sociodemographic characteristics, the mean years of diagnosis, and the score on the questionnaire. Statistically significant differences were only observed in years of schooling, with men reporting more years of schooling than women.

Table 1

Sociodemographic characteristics of sample studied

\begin{tabular}{lcccc}
\hline Variable & Total & Women & Men & $t$ \\
Age, years & $N=2022$ & $N=242$ & $N=1780$ & ${ }^{*} p<.01$ \\
Schooling, years & $31.9(9.3)$ & $28.2(10.9)$ & $33.5(15.1)$ & 1.349 \\
Diagnosis, years & $12.3(5.6)$ & $9.3(3.0)$ & $12.8(9.1)$ & $2.050^{*}$ \\
BDI-IA Score & $11.0(10.3)$ & $4.2(4.0)$ & $4.8(4.8)$ & .124 \\
\hline
\end{tabular}

Notes: BDI-IA: Beck Depression Inventory-IA; Mean (standard deviation). 
Table 2

Rotated component matrix with factor loads (> .40)

\begin{tabular}{|c|c|c|c|}
\hline \multirow[b]{2}{*}{ Item } & \multicolumn{3}{|c|}{ Component } \\
\hline & 1 & 2 & 3 \\
\hline Sense of failure & .716 & & \\
\hline Displeasure with oneself & .695 & & \\
\hline Guilt & .686 & & \\
\hline Punishment & .675 & & \\
\hline Pessimism & .660 & & \\
\hline Suicide ideation & .629 & & \\
\hline Sadness & .604 & & \\
\hline Anhedonia & .599 & & \\
\hline Self-criticism & .573 & & \\
\hline Indecisiveness & .516 & & \\
\hline Crying & .411 & & \\
\hline Tiredness & & .701 & \\
\hline Difficulty working & & .653 & \\
\hline Somatic work & & .647 & \\
\hline Hiporexia & & .623 & \\
\hline Insomnia & & .549 & \\
\hline Weight loss & & .525 & \\
\hline Loss of libido & & .454 & \\
\hline Social isolation & & & .591 \\
\hline Irritability & & & .585 \\
\hline Change in body image & & & .547 \\
\hline
\end{tabular}

Regarding the discrimination between items, since an average of $t=7.77(p<.05)$ was obtained between the groups at either extreme, no item was eliminated because of this criterion. An average Cronbach's $\alpha$ of .91 was obtained for the 21 questions. No items were removed because of this criterion.

For factor analysis, an orthogonal rotation (intercorrelations $r=.40 p<.01$ ) was used. The Kaiser-Meyer-Olkin measure of sufficiency for the sample was .929. As can be seen from Table 2, items were grouped into three factors.

The first factor (arranged from the highest to the lowest factorial load) grouped together the items of negative self-perception or general depression factor $(39.7 \%$ of explained variance). The second comprised the questions referring to the somatic factor (explaining $6.01 \%$ of the variance), while the third included the item on social dysfunction $(5.49 \%$ of explained variance).

As we can see in Table 3, the "negative self-perception" factor obtained a Cronbach's $\alpha$ of .89, the "somatic" factor .80 and the "social dysfunction" factor .66 .

According to the CFA indices of the two models evaluated, the one- and three-factor models fit the data adequately. The indices can be observed in Table 4, with a Hoelter adjustment index of 465 for $n=2022$.

Items in the first factor were analyzed as if they comprised the whole questionnaire (12 versus 21 items) and the mean scores were obtained in patients diagnosed with symptoms of major depressive disorder $(n=291)$, adjustment disorder $(n=809)$, and without symptoms. $(n=922)$. It was found that with a cut-off point of 11 no statistically significant differences were observed between groups above and below 11 in infection variables such as viral load, CD4, or years since diagnosis, $(t=1.70$ to $3.25, p=.09)$, although they were observed among patients with symptoms of major depressive disorder and without symptoms of mental disorder, yielding an area under the curve of $86.5 \%$ (AUC) $=.865 ; 95 \%$ CI $[.83, .90], p \leq .001$ (Figure 1$)$.

\section{DISCUSSION AND CONCLUSION}

This study tested the reliability and validity of the Mexican version of the BDI-IA in Mexican PLWH, and a short version was obtained based on the factor that explained the highest percentage of variance according to and supported by the CFA.

We consider that the results obtained for reliability and validity using the CFA support a short version for the screening of depression symptoms specifically for patients with HIV.

Table 3

Psychometric Properties of BDI-IA in PLWH

\begin{tabular}{lcccc}
\hline & $\begin{array}{c}\text { Average score/ } \\
\text { range: } 0-3\end{array}$ & Cronbach's $\alpha$ & $\begin{array}{c}\text { Explained } \\
\text { variance (\%) }\end{array}$ & $\begin{array}{c}\text { Item- total } \\
\text { correlation }\end{array}$ \\
\hline Negative perception of self (10) & .44 & .89 & $39.7 \%$ & $.52-.75$ \\
Somatic (8) & .57 & .80 & $6.01 \%$ & $.38-.66$ \\
Social Dysfunction (3) & .65 & .66 & $5.49 \%$ & $.40-.69$ \\
Total BDI & & .91 & $51.2 \%$ & \\
\hline
\end{tabular}

Table 4

Factorial structures analyzed and adjustment indices obtained for the BDI-IA in PLWH

\begin{tabular}{lcccc}
\hline Factorial structure & $X^{2} / d f$ & $T L I$ & CFI & RMSEA \\
\hline Unifactorial: All items are grouped into a single factor & 15.83 & .919 & .923 & $.070(.068-.072)$ \\
Three factors: Items are grouped into three different but correlated factors & 11.54 & .929 & .938 & $.053(.051-.055)$ \\
\hline
\end{tabular}






Figure 1. COR curve with an 11 cut-off point of the short version of the BDI-IA between major depressive disorder symptoms and no symptoms.

Replicating the methodology of the BDI-IA validation study for the Mexican population and analyzing the data in relation to the HIV infection variables, such as years of diagnosis, viral load, and CD4 cells was a good decision. Although we failed to find any differences in the comparison of groups based on the median age, we did report them in the years of schooling variable, in which men had more schooling. Although educational attainment has been defined as a variable that may increase the risk of acquiring HIV infection, we do not consider it to be a variable that has made it difficult to understand the questions in the case of women, who had a mean age comparable to age for having completed secondary school (Bautista-Arredondo et al., 2013).

The internal consistency coefficients of the questionnaire are comparable with the original version and the version adapted for the Mexican population, which supports the reliability of this version of the questionnaire in this HIV population. With respect to other published versions, the internal consistency coefficients of the BDI-IA were like those of the original version and slightly higher than those of the Mexican version. We obtained construct validity, thereby replicating the psychometric analysis procedure of the original version, and updated it with the current criteria, using CFA (DiPrete, Pence, Grelotti, \& Gaynes, 2018). This means that we can have a tool in Mexico for screening for depression symptoms in PLWH since several authors have highlighted the need for methods that have been validated in this population, which could be used on a massive scale and incorporated into decision-making (Eshun-Wilson et al., 2018; Perazzo et al., 2020).

In this study, we obtained data on cut-off points according to the diagnoses of adjustment disorder and major depressive disorder. We consider that this finding could be beneficial for use in outpatient settings for PLWH care (DiPrete et al., 2018). A cut-off point of $>11$ is suggested to be able to more specifically evaluate the depression symptoms of a PLWH who is going to begin ART, and above all, to confirm a diagnosis, provide treatment for depression by being clear about which symptoms existed prior to treatment, and be able to provide multidisciplinary management for these patients.

This is because we excluded participants with HIV symptoms compatible with an advanced stage of infection since, as we mentioned, several of the criticisms leveled at the use of both the BDI-IA and BDI-II state that the presence of symptoms of the infection could be associated with a ceiling effect in the Beck questionnaire scores, especially the somatic factor. This was one of the reasons for using the first version of the questionnaire. Since it has been studied more than the second version, there are more data and suggested methods for distinguishing somatic depression symptoms from those due to the progression of HIV. We analyzed the scores above and below the median viral load, CD4 cells and years since diagnosis, because a mixture of higher viral load and fewer defenses is associated with a more advanced degree of infection. Moreover, after crossing it with an expert's diagnosis, we can provide a better explanation associated with HIV symptoms or the somatic symptoms of depression (Chichetto et al., 2020; Ciesla \& Roberts, 2001; Nanni et al., 2015; Vos et al., 2015; White et al., 2015; Wolff, Alvarado, \& Wolff, 2010).

Nevertheless, this study has certain methodological limitations, such as using a sample of participants only from Mexico City (CDMX), obtained at a specific facility, and including very few women, which could mean that the comparisons by gender are skewed and may be more representative of CDMX men living with HIV rather than PLWH in general. This suggests we should continue with this line of research in groups of women living with HIV and in groups of PLWH in other parts of Mexico. In addition to the effect of infection on mood, there are psychosocial factors such as stigma, discrimination, and social support that may have a negative impact on mood, which are variables we did not consider for the purpose of this study (Hammond et al., 2016; Chichetto et al., 2020).

Not having a random sample may also have skewed the data, since only "regular" patients were considered. In other words, these patients do not have as many psychosocial challenges as those who are unable to attend on a regular basis due to psychosocial barriers, in whom we would expect to see a greater presence of affective symptoms.

A short version is therefore proposed since it has proved reliable, valid, sensitive, and specific for use with patients 
with HIV and considers a cut-off point of $\geq 11$ to more exhaustively evaluate symptoms that may be compatible with major depressive disorder.

\section{Funding}

None.

\section{Conflict of interest}

The authors declare they have no conflicts of interest.

\section{Acknowledgements}

We would like to thank the patients of the Condesa Specialized Clinic (Clínica Especializada Condesa) who voluntarily participated.

\section{REFERENCES}

American Psychiatric Association. (2015). Depressive Disorders: DSM-5 ${ }^{\circledR}$ Selections. American Psychiatric Pub.

Bautista-Arredondo, S., Colchero, M. A., Romero, M., Conde-Glez, C. J., \& SosaRubí, S. G. (2013). Is the HIV epidemic stable among MSM in Mexico? HIV prevalence and risk behavior results from a nationally representative survey among men who have sex with men. PloS One, 8(9), e72616. doi: 10.1371/ journal.pone.0072616

Beck, A. T., \& Steer, R. A. (1984). Internal consistencies of the original and revised Beck Depression Inventory. Journal of Clinical Psychology, 40(6), 1365-1367. doi: 10.1002/1097-4679(198411)40:63.0.co;2-d

Beck, A. T., Steer, R. A., \& Carbin, M. G. (1988). Psychometric properties of the Beck Depression Inventory: Twenty-five years of evaluation. Clinical Psychology Review, 8(1), 77-100. doi: 10.1016/0272-7358(88)90050-5

Beltrán, M. D. C., Freyre, M. Á., \& Hernández-Guzmán, L. (2012). El Inventario de Depresión de Beck: Su validez en población adolescente. Terapia Psicológica, 30(1), 5-13. doi: 10.4067/S0718-48082012000100001

Berger-Greenstein, J. A., Cuevas, C. A., Brady, S. M., Trezza, G., Richardson, M. A., \& Keane, T. M. (2007). Major depression in patients with HIV/AIDS and substance abuse. AIDS Patient Care and STDs, 21(12), 942-955. doi: 10.1089/ apc. 2006.0153

Byrne, B. M. (2010). Structural equation modeling with AMOS Basic concepts, applications, and programming (Multivariate Applications Series). Routledge/ Taylor \& Francis Group.

Carretero-Dios, H., \& Pérez, C. (2005). Normas para el desarrollo y revisión de estudios instrumentales. International Journal of Clinical and Health Psychology, 5(3), 521-551.

Centro Nacional para la Prevención y el Control del VIH/SIDA [CENSIDA]. (2018a). Vigilancia Epidemiológica de casos de VIH/SIDA en México, Registro Nacional de Casos de SIDA, actualización al ler. trimestre del 2018. México: Censida/Secretaría de Salud. Retrieved from https://www.gob.mx/cms/uploads/ attachment/file/328400/RN_1er_trim_2018.pdf

Centro Nacional para la Prevención y Control del VIH/SIDA [CENSIDA]. (2018b).

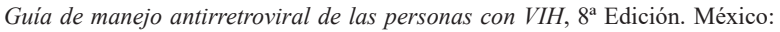
Censida/Secretaría de Salud. Retrieved from https://www.gob.mx/cms/uploads/ attachment/file/326631/Gu a ARV 2018.pdf

Chichetto, N. E., Polanka, B. M., So-Armah, K. A., Sung, M., Stewart, J. C., Koethe, J. R., \& Freiberg, M. S. (2020). Contribution of Behavioral Health Factors to Non-AIDS-Related Comorbidities: An Updated Review. Current HIV/AIDS Reports, 17(4):354-372. doi: 10.1007/s11904-020-00498-y

Ciesla, J. A., \& Roberts, J. E. (2001). Meta-analysis of the relationship between HIV infection and risk for depressive disorders. American Journal of Psychiatry, 158(5), 725-730. doi: 10.1176/appi.ajp.158.5.725

Dávila, Y., Castellanos, M., \& García, M. (2015). National strategy of integrated care for tuberculosis and HIV co-infection in Mexico, progress in 2015/. International Journal of Integrated Care, 15(8).

DiPrete, B. L., Pence, B. W., Grelotti, D. J., \& Gaynes, B. N. (2018). Measurement of depression treatment among patients receiving HIV primary care: Whither the truth? Journal of Affective Disorders, 230, 50-55. doi: 10.1016/j.jad.2017.12.068

Engler, K., Lènàrt, A., Lessard, D., Toupin, I., \& Lebouché, B. (2018). Barriers to antiretroviral therapy adherence in developed countries: a qualitative synthesis to develop a conceptual framework for a new patient-reported outcome measure. AIDS Care, 30(sup1), 17-28. doi: 10.1080/09540121.2018.1469725

Eshun-Wilson, I., Siegfried, N., Akena, D. H., Stein, D. J., Obuku, E. A., \& Joska, J. A. (2018). Antidepressants for depression in adults with HIV infection. The Cochrane Database of Systematic Reviews, 1(1), CD008525. doi: 10.1002/14651858.CD008525.pub3

Gebreyesus, T., Belay, A., Berhe, G., \& Haile, G. (2020). Burden of fatigue among adults living with HIV/AIDS attending antiretroviral therapy in Ethiopia. BMC Infectious Diseases, 20(1), 1-10. doi: 10.1186/s12879-020-05008-4

Gonzalez, J. S., Batchelder, A. W., Psaros, C., \& Safren, S. A. (2011). Depression and HIV/AIDS treatment nonadherence: a review and meta-analysis. Journal of Acquired Immune Deficiency Syndromes, 58(2). doi: 10.1097/ QAI.0b013e31822d490a

González-Celis Rangel, A. L. (2009). Composición factorial del inventario de depresión de Beck en ancianos mexicanos. Journal of Behavior, Health \& Social Issues, 1(1), 15-28.

Govender, R. D., \& Schlebusch, L. (2012). Hopelessness, depression, and suicidal ideation in HIV-positive persons. South African Journal of Psychiatry, 18(1), 16-21. doi: 10.4102/sajpsychiatry.v18i1.302

Guillemin, F. (1995). Cross-cultural adaptation and validation of heatth status measures. Scandinavian Journal of Rheumatology, 24(2), 61-63. doi: 10.3109/03009749509099285

Hammond, E. R., Crum, R. M., Treisman, G. J., Mehta, S. H., Clifford, D. B., Ellis, R. J., \& Morgello, S. (2016). Persistent CSF but not plasma HIV RNA is associated with increased risk of new-onset moderate-to-severe depression symptoms, a prospective cohort study. Journal of Neurovirology, 22(4), 479-487. doi: 10.1007/s13365-015-0416-1

Hudelson, C., \& Cluver, L. (2015). Factors associated with adherence to antiretroviral therapy among adolescents living with HIV/AIDS in low-and middleincome countries: a systematic review. AIDS Care, 27(7), 805-816. doi: 10.1080/09540121.2015.1011073

Jurado, S., Villegas, M. E., Méndez, L., Rodríguez, F., Loperena, V., \& Varela, R. (1998). La estandarización del Inventario de Depresión de Beck para los residentes de la Ciudad de México. Salud Mental, 21(3), 26-31.

Kalichman, S. C., Rompa, D., \& Cage, M. (2000). Distinguishing between overlapping somatic symptoms of depression and HIV disease in people living with HIV-AIDS. The Journal of Nervous and Mental Disease, 188(10), 662670. doi: 10.1097/00005053-200010000-00004

Mendoza, J. E. V., Ramírez, M. C., \& Morales, J. E. A. (2013). Estrategias de afrontamiento del sida en pacientes diagnosticados como seropositivos. Psicología y Salud, 19(2), 215-221. doi: 10.25009/pys.v19i2.631

Muhktar, F., \& Oei, T. P. (2008). Exploratory and confirmatory factor validation and psychometric properties of the Beck Depression Inventory for Malays (BDIMalay) in Malaysia. Malaysian Journal of Psychiatry, 17(1).

Nanni, M. G., Caruso, R., Mitchell, A. J., Meggiolaro, E., \& Grassi, L. (2015). Depression in HIV infected patients: a review. Current Psychiatry Reports, 17(1), 530. doi: 10.1007/s11920-014-0530-4

Nunnally, J. C., \& Bernstein, Y. J. (1994). Psychometric Theory (3rd Ed). New York: McGraw Hill.

Pala, A. N., Steca, P., Bagrodia, R., Helpman, L., Colangeli, V., Viale, P., \& Wainberg, M. L. (2016). Subtypes of depressive symptoms and inflammatory biomarkers: an exploratory study on a sample of HIV-positive patients. Brain, Behavior, and Immunity, 56, 105-113. doi: 10.1016/j.bbi.2016.02.013

Perazzo, J. D., Currie, J., Horvat Davey, C., Lambert, J., \& Webel, A. R. (2020). Depression and social capital in people living with HIV. Journal of Psychiatric and Mental Health Nursing, 27(1), 54-61. doi: 10.1111/jpm.12552

Reyes-Lagunes, I., \& García y Barragán, L. F. (2008). Procedimiento de validación psicométrica culturalmente relevante: Un ejemplo. In S. Rivera Aragón, R. Díaz Loving, R. SánchezAragón, I. Reyes Lagunes (Eds.). La psicología social en México, XII (pp. 625-630). México: AMEPSO, Universidad de Guanajuato y UNAM.

Rodríguez, V., Magis, C., Casillas, J., Ramirez, H. V., Hernandez, G., Rentería, C. R., \& Gonzalez, A. (2012). Internal consistency and factorial structure of the Beck Depression Inventory (BDI) in Mexican HIV-positive patients. Poster at XIX International AIDS Conference July (pp. 22-27).

Sowa, N. A., Bengtson, A., Gaynes, B. N., \& Pence, B. W. (2016). Predictors of depression recovery in HIV-infected individuals managed through measurementbased care in infectious disease clinics. Journal of Affective Disorders, 192 153-161. doi: 10.1016/j.jad.2015.12.031

Steer, R. A., Clark, D. A., Beck, A. T., \& Ranieri, W. F. (1999). Common and specific dimensions of self-reported anxiety and depression: the BDI-II versus the BDIIA. Behaviour Research and Therapy, 37(2), 183-190. doi: 10.1016/s00057967(98)00087-4 
Torres-Castillo, M., Hernández-Malpica, E., \& Ortega-Soto, H. A. (1991). Validez y reproducibilidad del inventario para Depresión de Beck, en un hospital de cardiología. Salud Mental, 14(2), 1-6.

Tsai, A. C. (2014). Reliability and validity of depression assessment among persons with HIV in sub-Saharan Africa: systematic review and meta-analysis. Journal of Acquired Immune Deficiency Syndromes, 66(5), 503-511. doi: 10.1097/ QAI.0000000000000210

Turan, B., Rice, W. S., Crockett, K. B., Johnson, M., Neilands, T. B., Ross, S. N., ... Turan, J. M.. (2019). Longitudinal association between internalized HIV stigma and antiretroviral therapy adherence for women living with HIV: the mediating role of depression. Aids, 33(3), 571-576. doi: 10.1097/QAD.0000000000002071

Uthman, O. A., Magidson, J. F., Safren, S. A., \& Nachega, J. B. (2014). Depression and adherence to antiretroviral therapy in low-, middle-and high-income countries: a systematic review and meta-analysis. Current HIV/AIDS Reports, 11(3), 291-307. doi: 10.1007/s11904-014-0220-1

Valdés, C., Morales-Reyes, I., Pérez, J. C., Medellín, A., Rojas, G., \& Krause, M. (2017). Propiedades psicométricas del Inventario de Depresión de Beck IA para la población chilena. Revista Médica de Chile, 145(8), 1005-1012.

Vos, T., Barber, R. M., Bell, B., Bertozzi-Villa, A., Biryukov, S., Bolliger, I., ... Duan,
L. (2015). Global, regional, and national incidence, prevalence, and years lived with disability for 301 acute and chronic diseases and injuries in 188 countries, 1990-2013: a systematic analysis for the Global Burden of Disease Study 2013. The Lancet, 386(9995), 743-800. doi: 10.1016/S0140-6736(15)60692-4.

White, J. R., Chang, C. C. H., So-Armah, K. A., Stewart, J. C., Gupta, S. K., Butt, A. A., ... Freiberg, M. S. (2015). Depression and human immunodeficiency virus infection are risk factors for incident heart failure among veterans: Veterans Aging Cohort Study. Circulation, 132(17), 1630-1638. doi 10.1161/ CIRCULATIONAHA.114.014443

Wolff, C., Alvarado, R., \& Wolff, M. (2010). Prevalencia, factores de riesgo y manejo de la depresión en pacientes con infección por VIH: Revisión de la literatura. Revista Chilena de Infectología, 27(1), 65-74.

World Health Organization. (2000). Guia de bolsillo de la clasificación CIE-10. clasificación de los trastornos mentales y del comportamiento. Editorial Médica Panamericana.

World Medical Association. (2013). World Medical Association Declaration of Helsinki: ethical principles for medical research involving human subjects. Journal of the American Medical Association, 310(20), 2191-2194. doi: 10.1001/jama.2013.281053.

\section{APPENDIX}

This questionnaire contains groups of sentences. Please read each one carefully and choose ONE sentence from each group that best describes how YOU HAVE FELT IN THE PAST WEEK, INCLUDING TODAY. Put an " $X$ " in the number next to the sentence you chose.

If several sentences from each group are equally important, circle each of them. MAKE SURE TO READ ALL THE SENTENCES IN EACH GROUP BEFORE MAKING YOUR CHOICE.

\begin{aligned} \hline 1) & \\ \cline { 2 - 2 } 0 & I don't feel sad. \\ 1 & I feel sad. \\ 2 & I feel sad all the time and I can't shake off that feeling. \\ 3 & I feel so sad or unhappy I can't bear it. \\ \hline 2 ) & \\ \hline 0 & I am not particularly discouraged about the future \\ 1 & I feel discouraged about the future. \\ 2 & I feel I cannot expect anything from the future. \\ 3 & I feel that the future irremediable and that things cannot im- \\ & prove. \\ \hline 3$) & \\$\hline 0 & I don't feel a failure. \\ 1 & I feel I have failed more than a normal person. \\ 2 & When I look back, the only thing I can see in my life is a bunch \\ & of failures. \\ 3 & I feel I am a complete failure as a person. \\ \hline 4$) & \\$\hline 0 & I continue to obtain as much pleasure from things as before. \\ 1 & I don't enjoy things as much as I used to. \\ 2 & Nothing really satisfies me anymore. \\ 3 & I find everything boring or unpleasant. \\ \hline 5 ) & \\ \hline 0 & I don't feel particularly guilty. \\ 1 & I feel guilty most of the time. \\ 2 & I feel quite guilty most of the time. \\ 3 & I feel guilty all the time. \\ \hline 6 ) & \\ \hline 0 & I don't feel I am being punished. \\ 1 & I feel I might be being punished. \\ 2 & I expect to be punished. \\ 3 & I feel I am being punished. \\ \hline & \end{aligned}

\begin{aligned} & \hline 7 ) \\ & \hline 0 I don't feel disappointed in myself. \\ & 1 I feel disappointed with myself. \\ & 2 I feel fed up with myself. \\ & 3 I hate myself. \\ & \hline 8) \\ & \hline 0 I don't feel worse than other people. \\ & 1 I criticize myself for my weakness or mistakes. \\ & 2 I blame myself all the time for my faults. \\ & 3 I blame myself for all the bad things that happen. \\ & \hline 9) \\ & \hline 0 I am not planning to kill myself. \\ & 1 I have ideas about killing myself, but I don't carry them out. \\ & 2 I would like to kill myself. \\ & 3 I would kill myself if I could. \\ &\hline 10$) \\ & 0$ I don't cry more than usual. \\ & 1 I cry more than before. \\ & 2 Now I cry all the time. \\ & 3 Before I was capable of crying but now, I can never cry even \\ & \hline if I want to. \\ & \hline 0 I make the same decisions I usually do. \\ & 1 I avoid making decisions more than before. \\ & 2 I find it more difficult to make decisions than I did before. \\ & 3 I can't make decisions any more. \\ &\hline 12$) \\ &$\hline 0 I have not noticed any recent changes in my interest in sex. \\ & 1 I am less interested in sex than I used to be. \\ & 2 I am much less interested in sex now. \\ & 3 I have completely lost interest in sex. \\ & \hline\end{aligned}

